\title{
ACADEMIC SUPERVISION TO IMPROVE TEACHER'S CAPABILITY IN ARRANGING ASSESSMENT ADMINISTRATION THROUGH DOCUMENT REVIEW AND GUIDANCE DURING THE COVID-19 PANDEMIC
}

\author{
Makmur \\ SMAN 2 Kampar, Kampar, Indonesia \\ makmur.bpc@gmail.com
}

\begin{abstract}
SUPERVISI AKADEMIK UNTUK MENINGKATKAN KEMAMPUAN GURU DALAM MENYUSUN ADMINISTRASI PENILAIAN MELALUI TELAAH DOKUMEN DAN PEMBIMBINGAN DIMASA PANDEMI COVID-19
\end{abstract}

\begin{tabular}{|c|c|}
\hline ARTICLE HISTORY & ABSTRACT \\
\hline $\begin{array}{l}\text { Submitted: } \\
18 \text { Desember } 2020 \\
18^{\text {th }} \text { December } 2020\end{array}$ & $\begin{array}{l}\text { Abstract: This study aims to determine how the planning, implementation, and follow-up steps } \\
\text { of academic supervision by supervisors to improve teacher competence in preparing } \\
\text { assessment administration. This research is action research. The data analysis technique used } \\
\text { in this study is a comparative descriptive analysis technique and quantitative data. The results } \\
\text { of the study indicate that academic supervision can improve teacher competence in arranging } \\
\text { assessment administration. Teacher competence in the initial conditions, cycle I and cycle II } \\
\text { showed the value of the teacher's ability in the preparation of the initial learning assessment } \\
\text { administration with an average of } 69.11 \text {, in the first cycle } 74.78 \text { and finally in the second cycle } \\
\text { with an average of } 78.11 \text { teachers in the preparation of learning assessment administration } \\
\text { from cycle to cycle. The amount of increase is } 5.67 \text { from the initial condition to the first cycle } \\
\text { and } 3.33 \text { from the first cycle to the second cycle. The conclusion from the research is that the } \\
\text { implementation of academic supervision can improve the ability of teachers in preparing } \\
\text { assessment administration. }\end{array}$ \\
\hline
\end{tabular}

Keywords: teachers, supervision

Accepted:

20 Mei 2021

$20^{\text {th }}$ May 2021

Published:

27 Juni 2021

$27^{\text {th }}$ June 2021
Abstrak: Penelitian ini bertujuan untuk mengetahui bagaimana langkah perencanaan, pelaksanaan, dan tindak lanjut supervisi akademik oleh pengawas untuk meningkatkan kompetensi guru dalam menyusun administrasi penilaian. Penelitian ini merupakan penelitian tindakan. Teknik analisis data yang digunakan dalam penelitian ini adalah teknik analisis deskriptif komparatif dan data kuantitatif. Hasil penelitian menunjukkan bahwa supervisi akademik dapat meningkatkan kompetensi guru dalam menyusun administrasi penilaian. Kompetensi guru pada kondisi awal, siklus I dan siklus II menunjukkan nilai kemampuan guru dalam penyusunan administrasi penilaian pembelajaran kondisi awal dengan rata-rata 69.11, pada siklus I yaitu 74.78 dan terakhir pada siklus II dengan rata-rata 78.11 Temuan ini mengindikasikan adanya peningkatan tingkat kemampuan guru dalam penyusunan administrasi penilaian pembelajaran dari siklus ke siklus. Besaran peningkatan 5.67 dari kondisi awal ke siklus I dan 3.33 dari siklus I ke siklus II. Simpulan dari penelitian bahwa pelaksanaan supervisi akademik dapat meningkatkan kemampuan guru dalam menyusun administrasi penilaian.

Kata Kunci: guru, supervisi

\section{CITATION}

Makmur, M. (2021). Academic Supervision To Improve Teacher's Capability In Arranging Assessment Administration Through Document Review And Guidance During The Covid-19 Pandemic. Primary: Jurnal Pendidikan Guru Sekolah Dasar, 10 (3), 723 729. DOI: http://dx.doi.org/10.33578/jpfkip.v10i3.8377. 


\section{PENDAHULUAN}

Pendidikan adalah usaha sadar dan terencana untuk mewujudkan suasana belajar dalam proses pembelajaran agar siswa secara aktif. Untuk mengembangkan potensi dirinya perlu memiliki kekuatan spiritual, keagamaan, pengendalian diri, kepribadian, kecerdasan, akhlak mulia, serta keterampilan yang diperlukan dirinya, masyarakat, bangsa dan negara. Dalam rangka mencapai tujuan pendidikan nasional yakni mencerdaskan kehidupan bangsa dan mengembangkan manusia seutuhnya, maka sangat besar peran guru sebagai pengajar dan pendidikan yang profesional, jabatan guru dituntut agar selalu berupaya meningkatkan pembelajaran dengan terus mengikuti perkembangan ilmu pengetahuan dan teknologi. Guru mengemban kewajiban untuk turut aktif membantu melaksanakan berbagai program pendidikan. Untuk memperoleh pendidikan yang baik maka kita sebagai guru perlu menyadari proses pembelajaran merupakan bagian yang penting. Guru memiliki peran yang sangat besar dalam mengorganisasikan kelas sebagai bagian dari proses pembelajaran dan siswa sebagai subjek yang sedang belajar.

Kepala sekolah sebagai supervisor merupakan seorang yang mampu membantu perkembangan anggota-anggota stafnya dalam meningkatkan mutu pendidikan. Menurut Adams dalam Donni (2014) menyatakan bahwa supervisi didefinisikan sebagai program berencana untuk memperbaiki pembelajaran. Supervisi adalah proses pembinaan yang diberikan kepada seluruh staf sekolah agar mereka dapat meningkatkan kemampuan untuk memperbaiki situasi belajar, serta mengembangkan situasi pembelajaran yang baik. Hasil supervisi berfungsi sebagai sumber informasi bagi pengembangan profesionalisme guru. Menurut Bafadal (2003) supervisi pendidikan didefinisikan sebagai proses pemberian layanan bantuan profesional kepada guru untuk meningkatkan kemampuannya dalam melak-sanakan tugas-tugas pengelolaan proses pembelajaran secara efektif dan efisien.
Dengan adanya pelaksanaan supervisi oleh kepala sekolah diharapkan memberi dampak terhadap terbentuknya sikap professional guru. Sikap professional guru merupakan hal yang amat penting dalam memelihara dan meningkatkan profesionalitas guru, karena selalu berpengaruh pada perilaku dan aktivitas keseharian guru. Perilaku profesional akan lebih diwujudkan dalam diri guru apabila institusi tempat ia bekerja memberi perhatian lebih banyak pada pembinan, pembentukan, dan pengembangan sikap profesional (Marianis, 2021).

Supervisi bukan untuk menghakimi kesalahan atau kekurangan guru dan warga sekolah untuk meningkatkan kualitas diri, mengekspresikan dan mengembangkan potensi diri. Hal ini seperti diungkapkan oleh Mulyasa (2004) bahwa memiliki hubungan yang erat antara mutu kepala sekolah dengan berbagai aspek kehidupan yang sekolah seperti disiplin sekolah, kualitas guru dan menurunkannya prilaku negatif peserta didik, hal ini juga berlaku bagi guru. Oleh karena itu, perlu diteliti bagaimana pelaksanaan supervisi di sekolah tersebut. Pelaksanaan supervisi diharapkan dapat memperbaiki kemampuan mengajar guru dan dapat meningkatkan kinerja guru dalam pembelajaran yang efektif.

Guru merupakan salah satu unsur yang dianggap sangat menentukan tinggi-rendahnya mutu pendidikan disekolah. Dalam meningkatkan kualitas sumberdaya manusia, guru mempunyai peran yang sangat penting. Keberhasilan siswa dalam belajar sangat dipengaruhi oleh bagaimana cara guru mengajar. Guru tidak hanya berfungsi mentransfer pengetahuan saja tetapi juga bertugas untuk memberikan keterampilan, merubah perilaku peserta didik. Untuk itu diperlukan guru yang profesional dalam pendidikan. Oleh karena itu kompetensi guru harus terus menerus dibina dan dikembangkan sehingga guru mampu menghasilkan pendidikan yang bermutu. Undang-Undang Nomor 14 Tahun 2005 tentang Guru dan Dosen mengemukakan bahwa seorang guru 
adalah pendidik profesional dengan tugas utama mendidik, mengajar, membimbing, mengarahkan, melatih, menilai, dan penerapan supervisi akademik untuk meningkatkan kompetensi guru dalam menyusun administrasi penilaian.

Namun, kenyataan masih jauh dari harapan atau belum sepenuhnya komponen itu dilaksanakan. Hasil wawancara dengan salah satu kepala sekolah yang berada di Kecamatan Kampar Hulu menunjukkan bahwa guru masih belum kompeten dalam menyusun administrasi penilaian pembelajaran dengan baik. Hal ini ditunjukkan dengan: 1) guru belum melaksanakan penilaian afektif, belum melaksanakan tugas secara tertruktur, belum melaksanakan program dan pelaksanaan remidial serta belum melakukan analisis hasil ulangan; dan 2) guru belum membuat program dan pelaksanaan remidial, belum melakukan analisis hasil ulangan serta belum membuat instrumen tes dan bank soal. Berdasarkan kondisi seperti telah dipaparkan di atas, maka pengawas dan kepala sekolah berupaya melakukan perbaikan dalam rangka peningkatan kompetensi pedagogik guru menggunakan supervisi akademik.

Kegiatan supervisi yang dilakukan oleh supervisor yaitu kepala sekolah terhadap kinerja guru belum menjadi kegiatan yang menyenangkan dan dinanti-nantikan oleh mereka. Kegiatan ini justru membuat mereka takut karena selama ini kegiatan supervisi bagi mereka identik dengan kegiatan-kegiatan mencari kesalahan baik dari pemeriksa kelengkapan pembelajaran sampai kepada pelaksanaan observasi kelas. Pemahaman guru tentang supervisi yang masih kurang menjadikan mereka tidak siap untuk disupervisi padahal bertujuan untuk meningkatkan kinerja guru. Selain itu, ketika telah dilaksanakannya supervisi akademik oleh kepala sekolah, belum terlihat umpan balik dari pelaksanaan tersebut, sehingga hasil peningkatan kinerja guru belum terlihat.

\section{METODE PENELITIAN}

Jenis penelitian yang digunakan adalah penelitian tindakan, model penelitian tindakan dari Kemmis dan Taggart (Arikunto, 2020) yaitu berbentuk spiral dari siklus yang satu ke siklus yang berikutnya. Setiap siklus meliputi planning (rencana), action (tindakan), observation (pengamatan), dan reflection (refleksi). Penelitian dilakukan di salah satu sekolah di Kecamatan Kampar Hulu. Subjek dalam penelitian adalah delapan orang guru. Instrumen penelitian yang digunakan dalam penelitian adalah Alat Penilaian Kemampuan Guru (APKG) dan instrumen penilaian administrasi pembelajaran dan kisi-kisi instrumen pengukuran. Metode pengumpulan data yaitu observasi dan dokumentasi. Analisis data yang digunakan adalah teknik analisis deskriptif.

\section{HASIL DAN PEMBAHASAN Hasil Penelitian}

Hasil penelitian pada siklus pertama ini, peneliti melakukan tindakan dengan melaksanakan pertemuan awal dengan dua orang guru pada salah satu sekolah yang dibinaan dengan memberikan pengarahan dan pembinaan terhadap guru dalam rangka supervisi akademik dalam menyusun administrasi penilaian. Pelaksanaan kegiatan pembinaan guru melalui supervisi akademik dilaksanakan satu kali pada sekolah binaan. Setelah peneliti melakukan proses penelitian dan pengawas juga telah melakukan observasi maka baik peneliti maupun kepala sekolah bersama-sama melakukan refleksi, seperti terlihat pada tabel 1 di bawah ini. 
ISSN : 2303-1514 | E-ISSN : 2598-5949

Tabel 1. Komparasi Tingkat Kompetensi Penyusunan Administrasi Penilaian Pembelajaran

\begin{tabular}{ccc} 
Pembelajaran & \multicolumn{2}{c}{$\begin{array}{c}\text { Tingkat Kompetensi Penyusunan } \\
\text { Administrasi Penilaian Pembelajaran }\end{array}$} \\
\cline { 2 - 3 } & Mean & Kenaikan \\
\hline Kondisi Awal & 69.11 & - \\
\hline Tindakan Siklus I & 74.78 & 5.67 \\
\hline
\end{tabular}

Berdasarkan tabel 1 di atas, diperoleh pada kondisi awal, rata-rata tingkat kompetensi penyusunan administrasi penilaian pembelajaran baru mencapai 69.11, setelah diberikan tindakan, rata-rata kompetensi penyusunan administrasi penilaian pembelajaran mencapai 74.78. Data ini menunjukkan peningkatan kompetensi penyusunan administrasi penilaian sebesar 5.67. Tabel 2 berikut memberikan gambaran distribusi dan visualisasi skor kondisi awal dan setelah diberi tindakan pada pelaksanaan suvervisi akademik.

Tabel 2. Distribusi FrekuensiTingkat Kompetensi Penyusunan Administrasi Penilaian Pembelajaran Kondisi A wal dan setelah Siklus I

\begin{tabular}{cccccc}
\hline \multirow{2}{*}{ Kategori } & \multirow{2}{*}{ Interval Skor } & \multicolumn{2}{c}{ Kondisi Awal } & \multicolumn{2}{c}{ Siklus I } \\
\cline { 3 - 6 } Baik Sekali & $91-100$ & F & \% & F & \% \\
\hline Baik & $76-90$ & 2 & $22.2 \%$ & 4 & $33.3 \%$ \\
\hline Cukup & $61-75$ & 4 & $44.4 \%$ & 3 & $27.7 \%$ \\
\hline Kurang & $51-60$ & 2 & $33.3 \%$ & & \\
\hline Kurang Sekali & $<50$ & & & & $\mathbf{1 0 0 \%}$ \\
\hline Total & & $\mathbf{8}$ & $\mathbf{1 0 0 \%}$ & $\mathbf{8}$ &
\end{tabular}

Tabel $2 \mathrm{di}$ atas terlihat bahwa kompetensi penyusunan administrasi penilaian pembelajaran mengalami peningkatan. Terlihat sudah tidak ada guru yang tidak melaksanakan penilaian afektif, sudah melaksanakan tugas secara tertruktur, sudah melaksanakan program dan pelaksanaan remidial serta sudah melakukan analisis hasil ulangan, ada 1 guru (33.3\%) pada kategori baik sekali, 4 guru $(38.8 \%)$ berada pada kategori baik dan 3 guru (27.7\%) berada pada kategori cukup.

Pada siklus kedua peneliti melakukan tindakan dengan melaksanakan pertemuan kedua untuk dengan melanjutkan pengarahan dan pembinaan terhadap guru dalam rangka supervisi akademik dalam menyusun administrasi penilaian. Selanjutnya, pemberian angket untuk langsung menjawab dan mengambil kesimpulan sebagai rencana kegiatan/pertemuan terakhir. Hasil tindakan supervisi memberikan gambaran peningkatan penyusunan administrasi penilaian pembelajaran dari kondisi siklus I Ke siklus II Skor capaian hasil penyusunan administrasi penilaian pembelajaran tersebut dirangkum dalam Tabel 3. Setelah peneliti melakukan proses penelitian dan pengawas juga telah melakukan observasi maka baik peneliti maupun kepala sekolah bersama-sama 
ISSN : 2303-1514 | E-ISSN : 2598-5949

melakukan refleksi (merenungkan kembali proses belajar mengajar yang telah dilakukan guru di sekolah yang dibina.

Tabel 3. Komparasi Tingkat kompetensi Penyusunan Administrasi Penilaian Pembelajaran

\begin{tabular}{ccc}
\hline \multirow{2}{*}{ Pembelajaran } & \multicolumn{2}{c}{$\begin{array}{c}\text { Tingkat Kompetensi Penyusunan } \\
\text { Administrasi Penilaian Pembelajaran }\end{array}$} \\
\cline { 2 - 3 } & Mean & \% Kenaikan \\
\hline Tindakan Siklus I & 74.78 & - \\
\hline Tindakan Siklus II & 78.11 & 3.33 \\
\hline
\end{tabular}

Dari data dalam tabel 3 di atas, diperoleh pada tindakan siklus $\mathrm{I}$, rata-rata tingkat kompetensi penyusunan administrasi penilaian pada siklus I mencapai 74.78 , setelah diberikan tindakan II, rata-rata kompetensi penyusunan administrasi penilaian pembelajaran mencapai 78.11.Data ini menunjukkan peningkatan kompetensi penyusunan administrasi penilaian pembelajaran sebesar 3.33. Pada tabel 4 berikut memberikan gambaran distribusi dan visualisasi skor kondisi awal, siklus I dan siklus II.

Tabel 4. Distribusi FrekuensiTingkat Kompetensi Penyusunan Administrasi Penilaian Pembelajaran Kondisi A wal, siklus I dan Siklus II

\begin{tabular}{cccccccc}
\hline \multirow{2}{*}{ Kategori } & $\begin{array}{c}\text { Interval } \\
\text { Skor }\end{array}$ & \multicolumn{2}{c}{ Kondisi Awal } & \multicolumn{2}{c}{ Siklus I } & \multicolumn{2}{c}{ Siklus II } \\
\hline & & F & \% & F & \% & F & \% \\
\hline Baik Sekali & $91-100$ & & & 1 & $33.3 \%$ & 5 & $55.5 \%$ \\
\hline Baik & $76-90$ & 2 & $22.2 \%$ & 4 & $38.8 \%$ & 2 & $44.4 \%$ \\
\hline Cukup & $61-75$ & 4 & $44.4 \%$ & 3 & $27.7 \%$ & 1 & $11.1 \%$ \\
\hline Kurang & $51-60$ & 2 & $33.3 \%$ & & & & \\
\hline Kurang Sekali & $<50$ & & & & & & $100 \%$ \\
\hline Total & & 8 & $100 \%$ & 8 & & 8 & $100 \%$
\end{tabular}

Dari tabel 4 terlihat bahwa kompetensi penyusunan administrasi penilaian pembelajaran mengalami peningkatan. Terlihat sudah tidak ada guru yang tidak melaksanakan penilaian afektif, dan sudah melaksanakan tugas secara terstruktur serta sudah melaksanakan program dan pelaksanaan evaluasi serta sudah melakukan analisis hasil ulangan, ada 10 guru $(55.5 \%)$ pada kategori baik sekali, 6 guru $(44.4 \%)$ berada pada kategori baik dan 2 guru $(11.1 \%)$ berada pada kategori cukup.

\section{Pembahasan}

Keberhasilan pendidikan tidak terlepas dari peranan supervisor di bidang pendidikan yang berupaya menemukan masalah-masalah pendidikan dan selalu memperbaiki kelemahan kelemahan yang terjadi. Dengan demikian pelaksanaan supervisi pengajaran oleh kepala sekolah di harapkan dapat meningkatkan kinerja guru dan pelaksanaan supervisi pengajaran akan optimal jika dilakukan langsung oleh kepala sekolah, karena kepala sekolah akan lebih banyak mengetahui kekurangan masing-masing guru dalam pelaksanaan belajar-mengajar. 
Salah satu tugas Kepala sekolah adalah melaksanakan kegiatan supervisi akademik. Menurut Olivia dalam Priansa dan Somad (2014) menyatakan bahwa kegiatan supervisi akademik dimaksudkan untuk: (a) Membantu guru dalam merencanakan pembelajaran; (b) Membantu guru dalam penyajian materi pembelajaran; (c) Membantu guru dalam mengevaluasi pembelajaran; (d) Membantu guru dalam mengelola kelas; (e) Membantu guru mengembangkan kurikulum; (f) Membantu guru dalam mengevaluasi kurikulum; (g) Membantu guru dalam mengevaluasi diri mereka sendiri; (h) Membantu guru bekerjasama dengan kelompok; (i) Membantu guru melalui inservice program.

Menurut Permendiknas RI Nomor 12 Tahun 2016, supervisi akademik yang dilakukan kepala sekolah antara lain: (a) Memahami konsep, prinsip, teori dasar karakteristik dan kecenderungan perkembangan tiap bidang pengembangan pembelajaran kreatif, inovatif, pemecahan masalah, berpikir kritis dan naluri kewirausahaan; (b) Membimbing guru dalam menyusun silabus tiap bidang pengembangan di sekolah atau mata pelajaran di sekolah berlandaskan isi, standar kompetensi, dan kompetensi dasar, dan prinsip-prinsip pengembangan kurikulum; (c) Pembimbing guru dalam memilih dan menggunakan strategi/ metode/ teknik pembelajaran/ bimbingan yang dapat mengembangkan berbagai potensi peserta didik; (d) Membimbing guru dalam melaksanakan kegiatan pembelajaran/bimbingan (di kelas, laboratorium, dan/atau dilapangan) untuk mengembangkan potensi peserta didik; (e) Membimbing guru dalam mengelola, merawat, mengembangkan dan menggunakan media pendidikan dan fasilitas pembelajaran; (f) Memotifasi guru untuk memanfaatkan teknologi informasi untuk pembelajaran.

Langkah pembinaan yang dilakukan supervisor dipercaya mampu dilaksanakan oleh guru yang disupervisi dengan tidak merasa terpaksa menerima saran supervisor dalam hal ini adalah kepala sekolah. Hubungan yang dibina secara demokratis dan kekeluargaan selama ini diharapkan menumbuhkan kreatifitas para guru, sehingga dapat berkomunikasi dengan baik oleh kedua belah pihak, yaitu antara guru yang disupervisi dengan kepala sekolah sebagai supervisor (Novianti, 2015). Terhadap permasalahan ini perlu adanya peningkatan kompetensi melalui pelatihan-pelatihan seiring dengan kemajuan ilmu pengetahuan dan teknologi sekarang ini yang selalu terjadi perubahan-perubahan dengan cepat dalam mengelola pendidikan dewasa ini. Di era globalisasi sekarang ini pendidikan mengalami perubahan, sehingga membuat penyelenggara pendidikan harus mengikuti arus perkembangan ilmu pengetahuan dan teknologi agar tidak ketinggalan dengan kemajuan jaman. Kepala sekolah sebagai salah seorang penentu maju mundurnya sekolah harus membuka diri seiring dengan perubahan jaman (Rambe, 2019). Dengan demikian jalan yang dapat ditempuh dengan menambah wawasan berpikir dan ilmu pengetahuan serta menguasai teknologi yang diperlukan melalui kegiatan pelatihan, diskusi, seminar dan kursus-kursus.

\section{SIMPULAN DAN REKOMENDASI}

Kegiatan pelaksanaan penelitian tindakan yang telah dilakukan selama dua siklus, dan berdasarkan seluruh pembahasan serta analisis yang telah dilakukan disimpulkan yaitu bahwa pelaksanaan supervisi akademik dapat meningkatkan kemampuan guru dalam menyusun administrasi penilaian. Rekomendasi berdasarkan hasil penelitian, yaitu (1) guru perlu mematangkan persiapan dalam melaksanakan administrasi penilaian, sehingga dapat meningkatkan mutu administrasi penilaian; (2) diperlukan adanya kegiatan penelitian lanjutan yang mengarah pada peningkatan kompetensi guru dalam menyusun administrasi penilaian. 
DAFTAR PUSTAKA

Arikunto, S., Suhardjono., \& Supardi. (2020). Penelitian Tindakan Kelas (Edisi Revisi). Jakarta: Bumi Aksara.

Bafadal, I. (2003). Peningkatan Profesionalisme Guru. Jakarta: Bumi Aksara.

Depdiknas. (2020). Undang-Undang Nomor 20 tahun 2003 tentang Sistem Pendidikan Nasional.

Depdiknas. (2005). Undang-Undang Nomor 14 Tahun 2005 tentang Guru dan Dosen.

Depdiknas. (2005). Peraturan Pemerintah Nomor 19 tahun 2005 tentang Standar Nasional Pendidikan.

Depdiknas. (2016). Permendiknas Nomor 16 tahun 2016 tentang Kualifikasi dan Kompetensi Guru.

Depdiknas. (2016). Permendiknas Nomor 12 tahun 2016 tentang Standar Pengawas Sekolah/Madrasah.

Donni, P. J., \& Rirmi, S. (2014). Manajemen Supervisi dan Kepemimpinan Kepala Sekolah. Bandung:Alfabeta.

Indrawati, E. (2017). Implementasi Supervisi Akademik di SMP. Manajemen Pendidikan, 11 (5), 491-497.

Marianis. (2021). Implementasi Supervisi Akademik Masa Pandemi Covid-19 Dalam Meningkatkan SDM SMPN 1 Sungai Pua. RADIANT Journal of Applied, Social, and Education Studies, 2(1), 27-40.

Mulyasa, E. (2004). Kurikulum Berbasis Kompetensi. Bandung:Remaja Rosdakarya Offset.

Novianti, H. (2015). Pelaksanaan Supervisi Akademik Kepala Sekolah dalam
Meningkatkan Kinerja Guru. Manajemen Pendidikan, 9 (2), 350358.

Priansa, D.J., \& Somad, R. (2014). Manajemen Supervisi dan Kepemimpinan Kepala Sekolah. Bandung: Alphabeta.

Rambe, M. (2019). Pelaksanaan Supervisi Akademik Sebagai Upaya untuk Meningkatkan Kompetensi Guru dalam Menyusun Rencana Pelaksanaan Pembelajaran. Jurnal PAJAR (Pendidikan dan Pengajaran), 3(4), 782-790. DOI: http://dx.doi.org/10.33578/pjr.v3i4. 7464. 